\title{
Urinveisinfeksjon blant eldre pasienter i hjemmesykepleien
}

\section{Ulikt kunnskapsnivå og upålitelig utstyr gjør det vanskelig for helsepersonell i hjemmesykepleien å oppdage og diagnostisere urinveisinfeksjon. Derfor trenger vi en nasjonal rettledende prosedyre for urinprøvetaking og bruk av urinstiks i hjemmesykepleien.}

\section{FORFATTERE}

Pia Cecilie Bing-Jonsson

Ph.d. og førsteamanuensis

Avdeling for sykepleievitenskap, Høgskolen i Sørøst-Norge

\section{Siri Tønnessen}

Ph.d. og førsteamanuensis

Avdeling for sykepleievitenskap, Høgskolen i Sørøst-Norge

\section{SAMMENDRAG}

Bakgrunn: Urinveisinfeksjon (UVI) er en hyppig forekommende infeksjon hos eldre pasienter i hjemmesykepleien. Rask og sikker diagnostisering av UVI er avhengig av at helsepersonell har kunnskaper om UVI, og at unders $\varnothing$ kelser som urinstikstest og urinprøvetaking blir gjennomført med så få feilkilder som mulig.

Hensikt: I denne artikkelen presenterer vi en kartlegging av hvilken kunnskap ansatte i hjemmesykepleien har om UVI og hvilken praksis som er knyttet til bruken av urinstiks og urinprøver. Formålet med studien var å identifisere mulige forbedringspunkter for praksis.

Metode: Vi utviklet et spørreskjema med 16 spørsmål, som ble sendt til 209 ansatte i hjemmesykepleien i seks ulike kommuner. 141 responderte (svarprosent på 67,5).

Resultat: Studien viser at flere forhold i praksis kan forbedres. Det er behov for kompetanseheving blant helsepersonellet når det gjelder å oppdage symptomer på UVI. Sentrale forbedringspunkter ved bruk av urinstiks er knyttet til avlesning, kunnskap om hvilket utslag man skal se på, og kunnskap om tilstrekkelig urinmengde. Utfordringer ved urinprøvetakingen handler om forurensning av urin, rutiner for forsendelse samt dokumentasjon.

Konklusjon: På bakgrunn av studiens funn mener vi det er hensiktsmessig å utvikle en nasjonal prosedyre for urinstiks og urinprøvetaking i hjemmetjenester. Det er også ønskelig å utvikle mer pålitelige og pasientvennlige diagnostiske verktøy for å diagnostisere UVI. 
Selv om mange eldre er ved god helse, henger økende alder sammen med grad av sykelighet $(1,2)$. En av de hyppigst forekommende bakterielle infeksjonene blant eldre er urinveisinfeksjon (UVI) (3). I 2014 var 59,3 prosent av dem som mottok helsetjenester i hjemmet, over pensjonsalder (4), noe som tilsier at mange av dem som får tjenester fra hjemmesykepleien, vil få UVI.

\section{DIAGNOSTISERING AV URINVEISINFEKSJON}

Typiske symptomer på UVI er svie og smerter ved vannlating, hyppig vannlating og feber, men hos eldre pasienter vil diffuse symptomer som forvirring, svimmelhet og $\varnothing \mathrm{kt}$ falltendens også kunne være symptomer på UVI $(2,3,5)$. Når helsepersonell registrerer symptomer på UVI hos eldre hjemmeboende pasienter, vil mange respondere med å ta en urinstikstest.

Hvis urinstiksen er positiv ved å gi utslag på nitritt og/eller leukocytter, kontakter helsepersonell som regel lege (6) over telefon, e-melding eller bes $\varnothing k$, og antibiotika blir forskrevet (7). Selv om UVI er den vanligste bakterielle infeksjonstypen, blir imidlertid eldre pasienter ofte overdiagnostisert og overbehandlet på grunn av diffuse symptomer og høy forekomst av asymptomatisk bakteriuri (ASB) $(5,8-10)$, som ikke skal behandles ifølge kliniske retningslinjer (11-14).

Til tross for at urinstiks er en hyppig anvendt undersøkelsesmetode, er det flere feilkilder ved bruk og tolkning av urinstiks knyttet til de ulike parameterne som leukocytter, nitritt med flere $(5,10,15)$. Mye tyder på at urinstiks er lite hensiktsmessig for å diagnostisere UVI hos eldre fordi den er lite pålitelig. Urinstiks kan heller ikke skille mellom UVI og ASB $(9,10$, 16).

I tillegg til å bruke urinstiks tas det derfor ofte en urinprøve som sendes til dyrking. For å få et pålitelig prøveresultat er det essensielt at urinprøven håndteres forsvarlig når det gjelder innsamling av urin, transport, oppbevaring, analyse og rapportering $(5,15)$. Slik det er i dag, finnes det ikke retningslinjer for urinprøvetaking i hjemmesykepleien, men for sykehus finnes det en gullstandard (17).

\section{RUTINER FOR URINPR ØVETAKING HAR FEILKILDER}

Mye tyder på at dagens rutiner for urinprøvetaking i hjemmesykepleien har flere feilkilder. Det er særlig utfordrende å få tatt urinprøve av pasienter som er inkontinente for urin og bruker urinabsorberende innlegg. Organiseringen av hjemmesykepleien innebærer ofte lange kjøreruter, der den ansatte er alene og skal betjene mange pasienter $f \varnothing r$ vedkommende er tilbake på hjemmesykepleiens kontor. Derfor kan det også være vanskelig å følge riktig fremgangsmåte knyttet til oppbevaring av urinprøver og forsendelse til mikrobiologisk undersøkelse (18).

\section{«Helsepersonell er usikre på om de har lest av urinstiksen korrekt fordi de ikke ser forskjell på fargenyansene på stiksen.»}

Symptombildet på UVI hos eldre er ofte atypisk (2), og påliteligheten til urinstiks og urinprøver er usikker. Derfor understreker flere hvor viktig det er med en helhetlig sykepleiefaglig tilnærming, der kartlegging av vitale mål som puls, temperatur og blodtrykk er helt sentralt $(9,10)$. Av dette følger at helsepersonell må ha kunnskap til å gjenkjenne symptomer og handle adekvat, slik at pasienter får den helsehjelpen de trenger. Etter søk i flere databaser har vi ikke funnet forskning som omhandler helsepersonells kunnskap knyttet til UVI eller hvordan urinstiks og urinprøver tas, behandles og avleses i hjemmesykepleien i Norge. Vi ønsker tiltak som kan bidra til rask og sikker diagnostisering, 
som også kan forhindre overbehandling av UVI.

\section{STUDIENS FORSKNINGSSPØRSMÅL}

Det er uklart hvilken kunnskap helsepersonell i hjemmesykepleien har om UVI og hvordan de gjennomfører $n \varnothing$ dvendige unders $\varnothing$ kelser i forbindelse med UVI. Av den grunn designet vi en studie som hadde til formål å identifisere mulige forbedringspunkter for praksis. Studien hadde følgende forskningsspørsmål:

- Hva er helsepersonells kunnskap om symptomer på UVI?

- Hvordan tas og behandles urinstiks og urinprøver i hjemmesykepleien?

- Hvordan erfarer helsepersonell nytten og avlesningen av parameterne på urinstikser?

\section{METODE}

DESIGN

Studien er designet som en tverrsnittsstudie. Vi utviklet et spørreskjema for å kartlegge kunnskap om UVI, bruk av urinstiks og urinprøvetaking. Spørreskjemaet inneholdt 16 spørsmål, hvorav elleve var multiple choice-spørsmål. To var åpne spørsmål, og tre var demografiske spørsmål (yrkesgruppe, antall år på arbeidsplass og type stilling). På de fleste spørsmålene var det mulig å oppgi flere svar. Forfatterne utviklet spørreskjemaet i samarbeid med en fagutviklingssykepleier og en leder for fag- og saksenheten i en norsk kommune. Spørreskjemaet ble testet for innholdsvaliditet $i$ to runder hos typiske respondenter, totalt seks ansatte i hjemmesykepleien. Disse respondentene tok stilling til hvorvidt spørreskjemaet var akseptabelt, forståelig, relevant for settingen og fri for tvetydigheter (19).

\section{DATASAMLING}

Vi inviterte seks kommuner på sørøstlandet, som takket ja til å delta i studien. Spørreskjemaet ble administrert elektronisk via Questback-spørreunders $\varnothing$ kelse. Inklusjonskriteriet for studien var at vedkommende jobbet i hjemmesykepleien, enten som fast ansatt, sykepleierstudent eller vikar. Alle ansatte i hjemmesykepleien i de seks kommunene ble invitert og oppfordret til å delta. De inviterte mottok et brev med informasjon om studien med internettlenke eller QR-kode til spørreskjemaet, eller e-post med informasjon og lenke til spørreskjemaet.

\section{ANALYSE}

Vi analyserte forskjeller mellom gruppene ved å bruke khikvadrattest og variansanalyse (ANOVA) der 1000 bootstrap-samples ble valgt siden normalfordeling ikke kunne tilskrives alle variabler. Analysene ble gjort ved hjelp av SPSS versjon 22. Et strengt nivå for statistisk signifikans ble satt til p?0,01 for å unngå såkalt multiple comparisons problem. Vi gjorde en faktoranalyse (principal factor analysis) av spørsmål 13 for å redusere de mange svaralternativene til mer håndterbare størrelser. Vi ekstraherte faktorer med egenverdi ?1 og brukte oblique rotasjon (direct oblim) fordi vi forventet at faktorene ville korrelere (20).

\section{RESULTAT}

Spørreundersøkelsen ble sendt til 209 ansatte i hjemmesykepleien, inkludert sykepleiere, helsefagarbeidere, sykepleiestudenter og assistenter eller ufaglærte, i seks norske kommuner. Av disse responderte 141 personer (svarprosent 67,5). Av respondentene var 49 prosent sykepleiere, 21 prosent helsefagarbeidere, 7 prosent ufaglærte, 3 prosent avdelingsledere og 20 prosent sykepleierstudenter. Sykepleierne hadde jobbet gjennomsnittlig 4,7 år i hjemmesykepleien, og 70 prosent av sykepleierne hadde fast stilling.

\section{HVA ER HELSEPERSONELLETS KUNNSKAP OM SYMPTOMER PÅ UVI?}

Spørsmål 2 i spørreskjemaet lyder som følger: «Hvilke symptomer ser du på som viktigste tegn på UVI?» Alle yrkesgruppene var enige om at forvirring er et viktig symptom på UVI, 
mens apati og anoreksi ikke er det. Tabell 1 viser hva helsepersonellet i hjemmesykepleien ser på som de viktigste symptomene på UVI hos sine pasienter. Symptomene er her rangert etter hva sykepleierne syntes var viktigst sammenliknet med hva de andre yrkesgruppene fant som viktigste tegn på UVI. For eksempel mener 90 prosent av sykepleierne at forvirring er et viktig symptom på UVI, mens 70 prosent av sykepleierstudentene synes det samme. Analysen viser at det var statistisk signifikant forskjell mellom gruppene på «redusert allmenntilstand», «svie ved vannlating» og «illeluktende urin». Det vil si at det var uenighet eller ulikt kunnskapsnivå om hvor viktig disse symptomene var.

Tabell 1: Kunnskap om symptomer på UVI, behandling av urinprøver og urinstiks samt nytte av urinstiksparametre

Svar oppgitt i prosent på følgende spørsmå:

- Spørsmål 2: Hvilke symptomer ser du på som viktige tegn på UVI?

- Spørsmål 4: Hva giør du når du ser at en pasient har symptom på uvi?

- Spøørmål 4: Hva gjør du når du ser at en puordan tar du en urinprøve?

- Spørsmål 11: Hva giør deg usikker på om du har lest av korrekt på urinstiksen?

\begin{tabular}{|c|c|c|c|c|c|c|}
\hline Hvilke symptomer ser du på som viktige tegn på UVI? & Sykepleier & Helsefagarbeider & Ufaglært & Student & $x^{2}$ & $p$-verdi \\
\hline Forvirring & 90 & 83 & 97 & 70 & 6,8 & .033 \\
\hline Redusert allmenntilstand & 83 & 55 & 83 & 60 & 11,9 & .001 \\
\hline Svie ved vannlating & 83 & 86 & 62 & 70 & 7,9 & .004 \\
\hline Illeluktende urin & 80 & 90 & 83 & 90 & 2,6 & .002 \\
\hline Hyppig vannlating & 77 & 66 & 79 & 60 & 4,3 & 027 \\
\hline Delirium & 33 & 24 & 17 & 10 & 4,4 & .030 \\
\hline Feber & 32 & 24 & 10 & 40 & 10,3 & .047 \\
\hline Konsentrert urin & 28 & 45 & 41 & 40 & 3,9 & 011 \\
\hline Dårlig matlyst & 23 & 7 & 14 & 20 & 6,6 & .020 \\
\hline Smerter over symfysen & 14 & 10 & 7 & 0 & 3,3 & 061 \\
\hline Apati & 6 & 0 & 0 & 20 & 11,3 & .086 \\
\hline Anoreksi & 1 & 0 & 0 & 0 & 16,8 & 057 \\
\hline \multicolumn{7}{|l|}{ Hva giør du når du ser at en pasient har symptom på UVI? } \\
\hline Ingenting, det er ikke mitt ansvarsområde & 1 & 0 & 0 & 0 & 1,1 & .489 \\
\hline Kontakter sykepleier for assistanse/råd & 14 & 34 & 90 & 38 & 26,7 & .001 \\
\hline Kontakter lege & 51 & 3 & 10 & 21 & 26,5 & .001 \\
\hline Tar urinstikstest & 96 & 100 & 60 & 93 & 21,7 & .047 \\
\hline Tar en urinprøve til dyrking & 67 & 59 & 10 & 55 & 12,2 & .018 \\
\hline Tar temperatur & 26 & 10 & 20 & 14 & 6,1 & 034 \\
\hline Tar puls & 10 & 7 & 10 & 0 & 3,6 & 017 \\
\hline Vurderer allmenntilstanden & 64 & 28 & 40 & 52 & 15,0 & 034 \\
\hline \multicolumn{7}{|l|}{ Hvordan tar du en urinprøve? } \\
\hline Pasient urinerer $\mathrm{i}$ bekken/pose/urinbeger under oppsyn & 94 & 100 & 90 & 97 & 2,7 & 106 \\
\hline Pasient engangskateteriseres & 41 & 21 & 0 & 17 & 11,7 & .002 \\
\hline Ber pasienten samle urin selv & 41 & 31 & 10 & 41 & 6,6 & .043 \\
\hline Bruker urin fra innlegg & 3 & 0 & 0 & 3 & 1,4 & 182 \\
\hline Jeg tar ikke urinprøver & 0 & 0 & 20 & 3 & 17,8 & .072 \\
\hline \multicolumn{7}{|l|}{ Hvor stikser du som oftest en urinprøve? } \\
\hline I pasientens hjem & 76 & 66 & 60 & 63 & 2,6 & .024 \\
\hline På kontoret/basen/sonen & 65 & 59 & 20 & 48 & 9,0 & .010 \\
\hline I eller utenfor bilen & 20 & 0 & 0 & 10 & 10,4 & 021 \\
\hline \multicolumn{7}{|l|}{$\begin{array}{l}\text { Hva gjør deg usikker på om du har lest av korrekt } \\
\text { på urinstiksen? }\end{array}$} \\
\hline Ser ikke forskjell på fargenyansene & 75 & 30 & 30 & 80 & 14,9 & .048 \\
\hline Vet ikke hvilket utslag jeg skal se på & 46 & 0 & 10 & 25 & 11,3 & .021 \\
\hline Vet ikke om urinstiksen fikk nok urin & 14 & 10 & 10 & 5 & 1,4 & .053 \\
\hline Vet ikke om urinen var forurenset & 46 & 70 & 10 & 35 & 8,1 & .030 \\
\hline Vet ikke om urinen var for gammel & 36 & 0 & 0 & 15 & 10,7 & 016 \\
\hline
\end{tabular}

Analysert ved hielp av khikvadrattest.

Spørsmål 4 «Hva gjør du når du ser at en pasient har symptom på UVI?» har til hensikt å kartlegge hvorvidt helsepersonellet kan handle adekvat på symptom på UVI. Resultatene fra spørsmål 4 (se tabell 1) viser at de aller fleste opplever UVI som sitt ansvarsområde, det vil si at helsefagarbeidere (34 prosent), studenter (38 prosent) og ufaglærte (90 prosent) kontakter sykepleier og ber om assistanse eller råd om hvordan de skal gå frem. Halvparten av sykepleierne oppgir at de kontakter lege, mens de aller fleste (med unntak av 40 prosent av de ufaglærte) tar en urinstiks når de ser at en pasient har tegn på UVI.

Det er varierende mellom yrkesgruppene hvor mange som tar en urinprøve, men 67 prosent av sykepleierne svarer at de tar en urinprøve ved symptom på UVI. Relativt få innenfor alle yrkesgruppene tar temperatur og puls (fra 0-26 prosent), mens 64 prosent av sykepleierne 
vurderer allmenntilstanden ved symptom på UVI.

\section{HVORDAN TAS OG BEHANDLES URINSTIKS OG URINPR $\emptyset$ VER?}

Spørsmål 5 kartlegger praksis for urinprøvetaking i hjemmesykepleien. Resultatene viser at for alle yrkesgruppene er det vanligste å la pasienten urinere i bekken, urinpose eller urinbeger under oppsyn (fra 94-100 prosent) (tabell 1). En del ber pasienten samle urin selv; 41 prosent av sykepleierne gjør dette. Spørsmål 12 har til hensikt å kartlegge praksis for urinstiksing. Resultatene viser at flertallet av helsepersonellet stikser en urinprøve $\mathrm{i}$ pasientens hjem eller på kontoret, basen eller sonen der de arbeider (fra 76-20 prosent) (tabell 1).

Spørsmål 13 lyder som følger: «Hvis du tar en urinprøve for dyrkning (for å sende til lege/laboratoriet), hvilke av de foreslåtte alternativene er gjenkjennbare for deg i din arbeidshverdag?» Faktoranalysen av svarene på dette spørsmålet ga fire faktorer som vi har gitt følgende navn: «ingen rutiner», «tilfeldig oppbevaring», «kunnskapsbaserte rutiner» og «usystematisk praksis». Tabell 2 viser resultatene fra faktoranalysen (20). Analyser av forskjellene mellom yrkesgruppene på de fire faktorene for urinprøvehåndtering viste at sykepleierne skårte høyest av yrkesgruppene på faktor 1 (ingen rutiner) og faktor 4 (usystematisk praksis) (statistisk signifikant).

Tabell 2: Faktorladninger, eigenvalues/egenverdier og forklart varians for spørsmål 13

\begin{tabular}{|c|c|c|c|c|}
\hline \multirow[b]{2}{*}{ Faktorer for urinprøvehåndtering (svaralternativ spørsmål 13) } & \multicolumn{4}{|c|}{ Faktorladninger } \\
\hline & 1 & 2 & 3 & 4 \\
\hline \multicolumn{5}{|l|}{ 13B: Urinprøven fraktes umiddelbart til kontoret/basen } \\
\hline \multicolumn{5}{|l|}{ Ingen rutiner } \\
\hline 13H: Vi har ingen faste rutiner på hvordan urinprøver skal forsendes & .786 & & -.325 & .313 \\
\hline $13 \mathrm{~N}$ : Sjelden anledning til å dokumentere noe ang. urinprøveforsendelse og urinstiks & .685 & & & .472 \\
\hline \multicolumn{5}{|l|}{ Tilfeldig oppbevaring } \\
\hline 13F: Det varierer fra gang til gang hvor lenge urinprøver oppbevares i romtemperatur & & .776 & & \\
\hline 13A: Urinprøven oppbevares i bil i flere timer før den settes kaldt & & .640 & & \\
\hline \multicolumn{5}{|l|}{ Kunnskapsbaserte rutiner } \\
\hline 13K: Jeg sender samme urinprøve som jeg stikset, til dyrking & & & .671 & \\
\hline 13D: Urinprøven settes kaldt med én gang jeg kommer til kontoret/basen & -.300 & & .600 & \\
\hline 13M: Etter forsendelse dokumenterer jeg helsetilstand, utslag på stiks og når forsend... & & & .586 & \\
\hline 13I: Urinprøve sendes sammen med informasjon om pasientens helsetilstand & -.385 & & .552 & \\
\hline 13G: Vi har fast rutine på hvordan urinprøver skal forsendes & & & .387 & \\
\hline \multicolumn{5}{|l|}{ Usystematisk praksis } \\
\hline 13L: Jeg sender en annen urinprøve til dyrking enn den som jeg stikset & & & & .636 \\
\hline 13E: Vi har en bestemt rutine for hvor raskt urinprøver skal settes kaldt & .558 & & & .564 \\
\hline 13J: Urinprøve sendes vanligvis ikke med informasjon om pasientens helsetilstand & .449 & & & .547 \\
\hline 13C: Urinprøven oppbevares i vanlig romtemperatur på kontor/base frem til avsendelse & & & & .391 \\
\hline Eigenvalues/egenverdier & 3.6 & 1.8 & 1.4 & 1.1 \\
\hline Andel varians & 25.6 & 13.0 & 10.1 & 7.5 \\
\hline Total andel varians $=56,3 \%$ & & & & \\
\hline
\end{tabular}

Kaiser-Meyer-Olkin-målet som bør være >.5 (22), hadde en verdi på. 752 , og Bartletts test som bør være signifikant, hadde en verdi på $<0.001$.

Ufaglærte skårte høyest på faktor 2 (tilfeldig oppbevaring) (ikke signifikant), og helsefagarbeidere skårte høyest på faktor 3 (kunnskapsbaserte rutiner) (ikke signifikant). Figur 1 gir en grafisk fremstilling av sykepleiernes andel av maksskår på de fire faktorvariablene - det vil si hvor høyt sykepleierne skårer i gjennomsnitt på faktorene i forhold til hva som var høyest mulig poengsum. Figuren viser at sykepleierne skårer høyest på kunnskapsbaserte rutiner. 


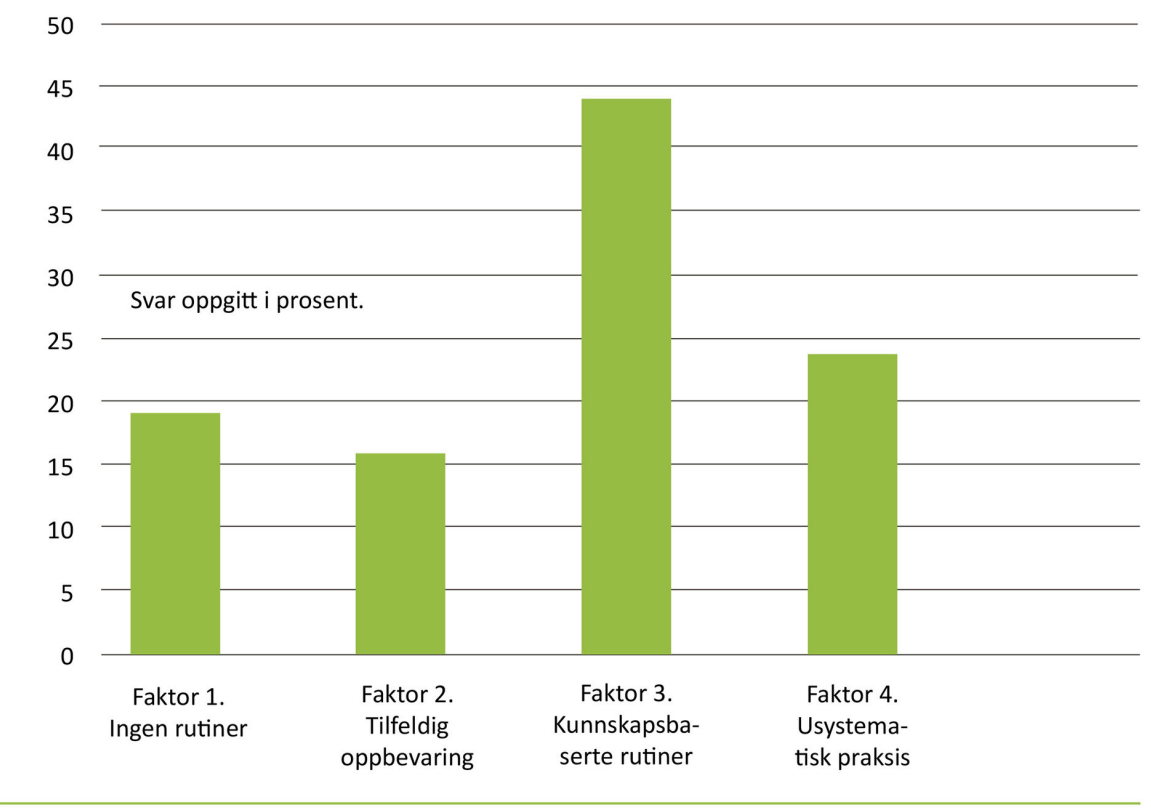

\section{HVILKEN NYTTE AV ELLER PROBLEMER HAR HELSEPERSONELLET MED URINSTIKS?}

Spørsmål 6 I $\varnothing$ d: «Hvis du tar en urinstiks for å unders $\varnothing$ ke om det er UVI, hvilke utslag på urinstiksen ser du på?» 81 prosent av sykepleierne svarte at de så på leukocytter. 97 prosent av sykepleierne så på nitritt, mens 48 prosent av sykepleierne også så på blod. Resultatet av spørsmål 7 viste at sykepleierne ser på glukose (74 prosent) og protein (62 prosent) som nyttige kliniske indikatorer. Resultatet av spørsmål 8 underst $\varnothing$ tter at indikatorene oppleves som nyttige, og at få sykepleiere mener at de bør fjernes (glukose 34 prosent, leukocytter 0 prosent, nitritt 5 prosent, proteiner 45 prosent og blod 5 prosent).

På spørsmålet «Er du noen gang i tvil om at du har lest av korrekt på urinstiksen?» svarte 41 prosent av sykepleierne, 37 prosent av helsefagarbeiderne, 100 prosent av de ufaglærte og 89 prosent av studentene «ja». Det som hovedsakelig gjør helsepersonellet usikre på om de har lest av urinstiksen korrekt, er at de ikke ser forskjell på fargenyansene på stiksen (fra 30-80 prosent) (tabell 1).

\section{DISKUSJON}

\section{KUNNSKAPER OM UVI}

Når det gjelder kunnskap om viktige symptomer på UVI, viser resultatene fra spørreundersøkelsen at helsepersonellet i hjemmesykepleien har kunnskap om kardinalsymptomene til UVI hos eldre. Slike kardinalsymptomer omfatter forvirring, redusert allmenntilstand, svie ved vannlating, illeluktende urin og hyppig vannlating (3). Studien vår tyder på at kunnskapsnivået til yrkesgruppene varierer, særlig når det gjelder vurdering av viktige symptomer som redusert allmenntilstand, svie ved vannlating og illeluktende urin.

Resultatene viser også at symptomer som kan oppleves som fordekte, slik som delirium, dårlig matlyst, smerter over symfysen, apati og anoreksi ikke ses som viktige tegn på UVI, selv om de regnes som mulige symptomer på UVI hos eldre $(3,21)$. For eldre pasienter er det typisk at sykdomstegn kan være fordekte og diffuse $(2,3,5)$. Det er derfor viktig at helsepersonellet har kunnskap om at for eksempel dårlig matlyst og apati også kan være uttrykk for en somatisk sykdom som UVI. 
kunnskap om at diffuse geriatriske symptomer kan være uttrykk for sykdom og funksjonssvikt. I så fall er dette bekymringsfullt, særlig når vi vet at i hjemmesykepleien er helsepersonellet som oftest alene hos pasientene. Kanskje er de også de eneste som er hos pasienten den dagen. Pasientene er avhengige av at alt personell har grunnleggende kompetanse til å handle adekvat for å gi tilstrekkelig og forsvarlig helsehjelp (22-24).

\section{«Eldre pasienter blir ofte overdiagnostisert og overbehandlet på grunn av diffuse symptomer og høy forekomst av asymptomatisk bakteriuri.»}

Når det gjelder å handle adekvat ved symptom på UVI, viser resultatene at de fleste blant helsepersonellet reagerer og agerer - enten ved å kontakte sykepleier for å be om hjelp, eller ved å kontakte lege, bruke urinstiks og/eller ta urinprøve. Ved mistanke om UVI blant eldre pasienter er bruk av urinstiks utbredt (3), noe resultatene i vår studie også viser.

En studie fra Canada fant at urinstiks blir brukt når helsepersonell mistenker UVI på bakgrunn av de typiske symptomene på UVI, men også ved endring av pasientens tilstand og ved mer diffuse symptomer som gråt og økt uro (6). Dette ser ut til å gjelde for Norge også, siden resultatene viser at flertallet av de faglærte tar urinstiks ved tegn på UVI. Den samme canadiske studien viste at sykepleiere observerer pasientens symptomer, ordinerer urinkulturer, tar urinstiks og har innvirkning på oppstart av antibiotika når de tar kontakt med lege (6). Derfor har de en sentral rolle i diagnostiseringen av UVI hos eldre.

Vi har grunn til å tro at sykepleiere i hjemmesykepleien i Norge også kan påvirke hvorvidt pasienter diagnostiseres med UVI eller ikke. Det er sykepleierne som er ansvarlige for den sykepleiefaglige behandlingen når de har vakt. I tillegg viser spørreundersøkelsen vår at annet helsepersonell agerer ved å kontakte og rådføre seg med sykepleier når de mistenker UVI.

Vi ser dermed hvor viktig det er at alt helsepersonell, og spesielt sykepleierne, har kunnskap om uttalte og fordekte symptomer på UVI hos eldre, slik at de kan gjøre de riktige vurderingene og deretter handle på en god måte. Derfor er det beklagelig at de færreste $\mathrm{i}$ vårt utvalg tar vitale mål som temperatur og puls. Det er også bekymringsfullt at relativt få vurderer allmenntilstanden som en del av en systematisk vurdering av helsetilstanden til pasienter med mistanke om UVI $(5,9,10)$.

\section{PRAKSIS FOR HVORDAN URINSTIKS OG URINPRØVER TAS OG BEHANDLES}

Når det gjelder praksis for urinprøvetaking i hjemmesykepleien, viste spørreunders $\emptyset$ kelsen at det vanligste er å la pasienter urinere i bekken, urinpose eller urinbeger under oppsyn, og at et mindretall ber pasienter samle urin selv. Det er en fordel at helsepersonell er til stede når pasienter urinerer fordi man da ser at urinsamlingen foregår hygienisk riktig, og dermed forhindrer forurensing av urinen. Så vidt vi vet, finnes det ikke noen nasjonal rettledende prosedyre for urinprøvetaking i hjemmesykepleien slik det finnes for sykehus (17).

Vi anbefaler en slik retningslinje fordi konteksten «hjemmesykepleie» er så variert. De hygieniske og utstyrsmessige forutsetningene som er til stede i sykehus, mangler ofte i hjemmesykepleien (25). De hygieniske prinsippene i prosedyren for urinprøvetaking i sykehus vil nødvendigvis også måtte gjelde for hjemmesykepleien for å hindre forurensete urinprøver. Det er viktig at helsepersonellet passer på at det er midtstrålen av urin som samles. Når man samler urin av midtstrålen må forhuden holdes tilbake eller kjønnsleppene holdes fra hverandre. Underlivet må vaskes når pasienten er inkontinent for urin $(15,17,26)$. 


\section{"I dag finnes det ikke retningslinjer for urinprøvetaking i hjemmesykepleien.»}

Undersøkelsen viste at helsepersonellet stikser en urinprøve i pasientens hjem eller på kontoret, basen eller sonen der de arbeider. Ved å stikse urinprøven i pasientens hjem, forutsatt at urinen er fersk, sikres urinen mot ytterligere bakterieoppvekst på grunn av for lang oppbevaringstid, for eksempel i bilen. Med veiledning fra kompetent personell kan stiksing på kontor, base eller sone være mer hygienisk. Imidlertid må oppbevaringstiden $\mathrm{i}$ romtemperatur fra prøven er tatt til den blir stikset, ikke overstige to timer (18).

Faktoranalysen viste at svaralternativene for urinprøvehåndtering (spørsmål 13) grupperte seg i fire faktorer, hvorav tre faktorer måler uhensiktsmessig praksis og én faktor måler kunnskapsbasert praksis $(17,18)$. Som figur 1 viser, er sykepleierne nærmest maksskår på kunnskapsbaserte rutiner. Likevel er det langt igjen til at alle sykepleiere oppnår full skår på det som er ønsket praksis:

- Urinprøven må settes kaldt med én gang sykepleier kommer til kontoret eller basen.

- Sykepleier må sende samme urinprøve til dyrking som hun/han stikset.

- Sykepleierne må ha en fast rutine på hvordan urinprøver forsendes.

- Urinprøven må sendes sammen med informasjon om pasientens helsetilstand.

- Etter forsendelsen må sykepleier dokumentere pasientens helsetilstand, utslag på stiks og når forsendelsen foregikk.

Siden det ikke finnes en nasjonal rettledende prosedyre for urinprøvetaking i hjemmesykepleien, anbefaler vi at en slik prosedyre utvikles. Det kan sikre mer forsvarlig, systematisk og kunnskapsbasert sykepleie til pasienter med UVI i hjemmesykepleien.

\section{NYTTE AV OG PROBLEMER MED URINSTIKS}

En nylig publisert litteraturstudie viser at for eldre er det kun nitritt og leukocytter alene, eller i kombinasjon, som er nyttige urinstiksindikatorer på bakterier i urinen (16). Det er derfor betryggende at sykepleierne i spørreundersøkelsen hovedsakelig ser på leukocytter og nitritt som indikatorer på UVI på urinstiks. De andre indikatorene glukose, proteiner og blod ble ansett som nyttige indikatorer på andre tilstander, noe som er i tråd med at urinstiks ikke bare er et diagnostisk verktøy for UVI.

Når det gjelder problemer med urinstiks, uttrykte alle de ufaglærte at de var usikre på hvordan de skulle lese av urinstiksen. Også flere av helsefagarbeiderne og sykepleierne var usikre på det samme. I hovedsak er helsepersonellet usikre på om de har lest av urinstiksen korrekt fordi de ikke ser forskjell på fargenyansene på stiksen.

\section{"Siden det ikke finnes en nasjonal rettledende prosedyre for urinprøvetaking i hjemmesykepleien, anbefaler vi at en slik prosedyre utvikles.»}

Litteraturstudien nevnt over viser at det er store svakheter med urinstiks som diagnostisk verktøy for UVI hos eldre (16). Urinstiks gir mange falske positive utslag, og den skiller ikke mellom faktisk bakteriuri og ASB som ikke skal behandles (11). Litteraturstudien viser at til tross for disse svakhetene har vi ikke noe bedre diagnostisk verktøy tilgjengelig.

I tillegg til de diagnostiske svakhetene ved urinstiks viser spørreundersøkelsen her at det er store usikkerhetsmomenter knyttet til hvorvidt helsepersonellet leser av urinstiksen korrekt. Derfor ser det ut til at urinstiks ikke er et pålitelig verktøy i hjemmesykepleien. Sammen med 
annen forskning (27) understreker dette behovet for et mer pålitelig verktøy til å

diagnostisere UVI. Et nytt verktøy må ta høyde for diagnostiske svakheter ved urinstiks, men også usikkerheten ved subjektive variasjoner i avlesning og tolkning.

\section{KONKLUSJON}

Hensikten med denne studien var å kartlegge kunnskap om UVI hos helsepersonell i hjemmesykepleien. Vi ønsket også å kartlegge hvordan urinstiks og urinprøver tas, behandles og avleses i hjemmesykepleien. Formålet med studien var å identifisere mulige forbedringspunkter for praksis. Spørreundersøkelsen tyder på at praksis kan forbedres på flere punkter: Helsepersonell i hjemmesykepleien trenger mer kunnskap om spekteret av symptomer hos eldre pasienter som kan vise seg å være forbundet med UVI, slik at flere tilfeller kan oppdages og diagnostiseres tidligere. Samtidig er det viktig å tenke helhetlig da sykdomstegn hos eldre pasienter kan være både diffuse og fordekte, og kan være uttrykk for andre sykdomstilstander enn bare UVI. Systematiske, kliniske observasjoner er nødvendige for å følge utviklingen av pasientens helsetilstand.

Selve urinprøvetakingen kan forbedres når det gjelder forurensing av urin, rutiner for sikker forsendelse samt dokumentasjon av nødvendige og tilstrekkelige opplysninger om pasientens helsetilstand. Problemområder for urinstiks ser ut til å være avlesning, men også manglende kunnskap om hvilket utslag man skal se på, hva som er nok urin, hva som er kilder til forurensning og hvor lenge urinen kan stå oppbevart. På bakgrunn av disse funnene anbefaler vi et det utvikles en nasjonal rettledende prosedyre for urinprøvetaking og bruk av urinstiks i hjemmesykepleien i Norge. Vi anbefaler også at det utvikles og forskes frem mer pålitelige og pasientvennlige diagnostiske verktøy for UVI tilpasset den eldre pasientgruppen, særlig pasienter som bruker urinabsorberende innlegg som det er vanskelig å få samlet urinen fra.

\section{REFERANSER}

1. Daatland SO, Veenstra M. Komparative perspektiver på omsorgstjenestene - Norge i en internasjonal sammenheng. I: Daatland SO, Veenstra $M$ (red.). Bærekraftig omsorg? Familien, velferdsstaten og aldringen av befolkningen NOVA-rapport nr. 2/2012. Oslo: Norsk institutt for forskning om oppvekst, velferd og aldring (NOVA); 2012. p. 175-86.

2. Beckett CL, Harbarth S, Huttner B. Special considerations of antibiotic prescription in the geriatric population. Clinical Microbiology and Infection 2015;21(1):3-9.

3. Wyller TB. Geriatri : en medisinsk lærebok. Oslo: Gyldendal Akademisk. 2015.

4. Statistisk Sentralbyrå. Kommunale helse- og omsorgstjenester 2014 Statistikk om tjenester og tjenestemottakere Rapporter 2015/42 Tilgjengelig fra:

http://ssb.no/helse/artikler-og-publikasjoner/kommunale-helse-og-omsorgstjenester-2014. (Nedlastet 15.10.2015).

5. Nazarko L. Treating the patient or the labstick? Urinary infections in older people. British Journal of Healthcare Assistants 2008;2(7):323-26.

6. Walker S, McGeer A, Simor A, Armstrong- Evans M, Loeb M. Why are antibiotics prescribed for asymtomatic bactiuria in institutionalized elderly people? A qualitative study of physicians' and nurses' perceptions. Canadian Medical Association Journal 2000;163(3):273-7.

7. Pettersson E, Vernby A, Molstad S, Lundborg CS. Infections and antibiotic prescribing in Swedish nursing homes: a cross-sectional study. Scand J Infect Dis. 2008;40(5):393-8. 
8. Bevridge LA, Davey PG, Phillips G, McMurdo ME. Optimal management of urinary tract infections in older people. Clinical Interventions in Aging 2001;6:173-80.

9. McNulty C. Managing asymptomatic bacteriuria in the elderly. Practice Nursing 2014;25(1):11-5.

10. Nazarko L. Recurrent urinary tract infection in older women. Nurse Prescribing 2014;12(12):608-13.

11. Helsedirektoratet. Nasjonale faglige retningslinjer for antibiotikabruk i primærhelsetjenesten.Tilgjengelig fra: https://helsedirektoratet.no/retningslinjer/nasjonal-faglig-retningslinje-for-antibiotikabruk-i-primerhelsetjenesten . (Nedlastet 08.11.2016).

12. High K, Schmader KE, Sokol HN. Evaluation of infection in the older adult.Tilgjengelig fra:

http://www.uptodate.com/contents/evaluation-of-infection-in-the-older-adult?source=search_result\&amp;search=infection+elderly\&amp;selecte dTitle=1\%7E13\#H1498008. (Nedlastet 14.04.2016).

13. Fekete T, Hooton TM, Calderwood SB, Bloom A. Approach to the adult with asymptomatic bacteriuria.Tilgjengelig fra: http://www.uptodate.com/contents/approach-to-the-adult-with-asymptomatic-bacteriuria . (Nedlastet 01.05.2015).

14. Scottish Intercollegiate Guidelines Network. Management of suspected bacterial urinary tract infection in adults SIGN guideline 88.Tilgjengelig fra: http://www.sign.ac.uk/guidelines/fulltext/88/recommendations.html . (Nedlastet 20.04.2016).

15. Dolan VJ, Cornish NE. Urine specimen collection: How a multidisciplinary team improved patient outcomes using best practices. Urologic Nursing. 2013;33(5):249-56.

16. Eriksen SV, Bing-Jonsson PC. Kan vi stole på urinstiks? Tilgjengelig fra: https://sykepleien.no/forskning/2016/09/kan-ikke-stole-blindt-pa-urinstiks. (Nedlastet 04.11.2016).

17. Kunnskapssenteret. Fagprosedyre: Urinprøve til bakteriologisk unders $\varnothing$ kelse.Tilgjengelig fra: http://www.helsebiblioteket.no/fagprosedyrer/ferdige/urinprove-til-bakteriologisk-undersokelse . (Nedlastet 08.11.2016).

18. Noklus. Urinprøve til mikrobiologisk unders $\emptyset$ kelse.Tilgjengelig fra: http://www.noklus.no/Portals/2/Forskning\%20og\%20utvikling/Bruk\%20av\%20urinprover\%20hos\%20eldre\%20-\%20for\%20allmennlege_\%20Noklu s\%202016.pdf. (Nedlastet 08.11.2016).

19. John OP, Benet-Martinez V. Measurement: Reliability, Construct Validation, and Scale Construction. I: Reis HT, Judd CM (red.). Handbook of Research Methods in Social and Personality Psychology. 1. Cambridge: Cambridge University Press. 2000. p. 33--69.

20. Field A. Discovering statistics using IBM SPSS statistics. Los Angeles: SAGE. 2013. 915

p.

21. Rowe TA, Juthani-Mehta M. Diagnosis and management of urinary tract infection in older adults. Infect Dis Clin North Am. 2014;28(1):75-89.

22. Tønnesen S. Faglige forutsetninger for forsvarlighetsbegrepet. Oslo: Sykepleien 
Forskning. 2013;2(8):148-55. Tilgjengelig fra: https://sykepleien.no/forskning/2013/04/faglige-forutsetninger-forsvarlighetsbegrepet . (Nedlastet 04.11.2016).

23. Bing-Jonsson PC, Bjørk IT, Foss C. The competence gap in community elderly care: Imbalance between expected and actual nursing staff competence. Nordic Journal of Nursing Research 2015.

24. Bing-Jonsson PC, Hofoss D, Kirkevold M, Bjørk IT, Foss C. Sufficient competence in community elderly care? Results from a competence measurement of nursing staff. BMC Nursing 2016;15(5).

25. Fjørtoft A-K. Hjemmesykepleie : ansvar, utfordringer og muligheter. 2. utg. Bergen: Fagbokforlaget. 2012.

26. Wisnes C. Urinprøvetaking - kunnskapsbasert eller tilfeldig? Oslo: Sykepleien.

2002;90(6):58-61. Tilgjengelig fra: https://sykepleien.no/forskning/2009/03/urinprovetaking-kunnskapsbasert-eller-tilfeldig . (Nedlastet 12.11.2016).

27. Hartley S, Valley S, Kuhn L, Washer LL, Gandhi T, Meddings J et al. Inappropriate testing for urinary tract infection in hospitalized patients: An opportunity for improvement. Infect Control Hosp Epidemiol. 2013;34(11):1204-7. 